\title{
Prognostic Factors in Predicting Primary Brainstem Hemorrhage Patients: An Experience in Indonesia's Rural Hospital
}

\author{
Namira Khairunnisa', Feda Anisah Makkiyah ${ }^{1, *}$, Tashya Anggraeni Sinaga ${ }^{1}$, Rahmah Hida Nurrizka ${ }^{2}$
}

Namira Khairunnisa', Feda Anisah Makkiyah ${ }^{1, *}$, Tashya Anggraeni Sinaga', Rahmah Hida Nurrizka²

'Faculty of Medicine, Universitas Pembangunan Nasional Veteran Jakarta, INDONESIA.

${ }^{2}$ Faculty of Public Health, UIN Syarif

hidayatullah, Jakarta

\section{Correspondence}

Feda Makkiyah

Faculty of Medicine, Universitas Pembangunan Nasional Veteran Jakarta, INDONESIA.

\section{E-mail: fedaanisah@upnvj.ac.id}

History

- Submission Date: 12-05-2021.

- Review completed: 27-06-2021;

- Accepted Date: 02-07-2021.

DOI : 10.5530/pj.2021.13.183

Article Available online

http://www.phcogj.com/v13/i6

\section{Copyright}

(C) 2021 Phcogj.Com. This is an openaccess article distributed under the terms of the Creative Commons Attribution 4.0 International license.

\begin{abstract}
Background: Primary brainstem hemorrhage is a rare type of hemorrhagic stroke with a very high reported mortality rate in Indonesia. Aim: This study aims to demonstrate the mortality rate of cases in one of Indonesia's rural hospitals. To help reduce the mortality rate, the prognostic factors of several cases were studied. These steps are needed to be able to predict the prognosis of primary brainstem hemorrhage patients and to give a better explanation to the family of the patients. Methods: A cross-sectional study was undertaken with collecting medical and radiological records from January 2018 to August 2020. A total sampling technique was done, and 340 patients were diagnosed with hemorrhagic stroke during that period. Only ten patients met the inclusion criteria and were included as the study samples. Statistical analysis using SPSS 22 and the Spearman correlation test adjusted for each variable. Results: Low prevalence of primary brainstem hemorrhage (7\%). There were correlation between GCS score, brainstem hemorrhage location, and length of stay with the patient's prognosis. Conclusion: Understanding these prognostic factors would reduce the prevalence of this primary brainstem hemorrhage and to ease the process of explaining the patients' condition to the family.

Key words: Brainstem, Factor, Intracerebral hemorrhage, Primary, Prognosis
\end{abstract}

\section{INTRODUCTION}

Spontaneous intracerebral hemorrhage (ICH) is a collection of blood in the brain parenchyma or ventricle that is caused by non-traumatic incidence. ${ }^{1}$ ICH can be classified into lobar and deep ICH. Lobar ICH includes cortical-subcortical areas, whereas deep ICH includes basal ganglia, internal capsule, cerebellum, and brainstem. ${ }^{2}$

Brainstem hemorrhage refers to bleeding that happens in the pons, pontomedullary junction, pontomesencephalic junction, midbrain, and medulla oblongata. ${ }^{3}$ The prevalence of this kind of stroke is $5-10 \%{ }^{7}$ with its main risk factor is hypertension ${ }^{4-6}$

Brainstem hemorrhage correlates with poor outcomes. $^{8}$ In the previous study, the mortality rate reached $57,5 \% .{ }^{9}$ Other studies said that the mortality rate of brainstem hemorrhage was $56 \%$ and $60-90 \% .^{10,11}$ The outcome of brainstem hemorrhage is variable, ranging from early death to long-term survival without neurological deficit, depending on clinical severity and radiological appearance. ${ }^{12,13}$

Higher mortality rate, varied management of brainstem hemorrhage, unestablished risk factors, lack of markers ${ }^{9}$ to predict the outcome of brainstem hemorrhage, and lack of studies on prognosis of brainstem hemorrhage in Indonesia were the background of this study. Another reason for the background of the study was the still ineffective multi strategic management with poor outcomes. ${ }^{14}$ This study will widen the reference of the evidence-based medicine of brainstem hemorrhage in Indonesia.

\section{METHODS}

\section{Patients}

Data gathered from a patient's medical record from January 2018 to August 2020 at Cileungsi District Hospital. Cileungsi is an outskirt area of Jakarta (capital city of Indonesia) that is located about $50 \mathrm{~km}$ from Jakarta. However, the majority of the patients live in the rural area with difficult access to health facilities.

Of 340 patients with hemorrhagic stroke, 23 patients were diagnosed with brainstem hemorrhage. We excluded etiology such as a tumor, arteriovenous malformation, and cavernoma were excluded. Next, the location of the hemorrhage should be in braistem. Patients with anticoagulant consumption were also excluded. Patients with hemorrhagic stroke in whom the involvement of the brainstem was an extension of the hemorrhagic stroke from other brain areas were also excluded.

The independent variables were age, sex, level of consciousness which assessed with Glasgow Coma Scale score, systolic blood pressure, diastolic blood pressure, hemorrhage volume, brainstem location, white blood cell count, blood glucose level, extension to the ventricle, hydrocephalus, insertion of extraventricular drainage, and length of stay. Based on CT Scan appearance, the location of hemorrhage was notified in pons, or midbrain or pons and midbrain or pons and medulla oblongata or pons, midbrain, and medulla oblongata.

The dependent variable was the outcome at discharge and at three months after discharge which was determined using modified Rankin Score (mRS). For the purpose of data analysis, $\mathrm{mRS}$ is divided into two 
groups, which are mRS 0, 1, 2 defined as good outcome and mRS 4, 5, 6 defined as poor outcome.

\section{Statistical analysis}

We used Chi Square, Fisher's exact, Kolmogorov-smirnov, and Spearman correlation tests to assess relationship between each of independent variables and dependent variable. Analyis data was utilized using SPSS software. There were two radiology assistants that were double blinded to the study to identify the location of brainstem hemorrhage based on CT scan appearance.

\section{Ethical declaration}

This study was approved by Universitas Pembangunan Nasional Veteran Jakarta Number 2767/IX/2020/KEPK.

\section{RESULTS}

From January 2018-August 2020, 340 hemorrhagic stroke patients were admitted to Cileungsi District Hospital. Among hemorrhagic stroke patients, 23 patients were diagnosed with brainstem hemorrhage, but only 10 patients fulfilled the inclusion criteria. Table 1 shows characteristics of brainstem hemorrhage patients.

Of 10 brainstem hemorrhage patients, $6(6 \%)$ were male and $4(4 \%)$ were female with the mean age $47,40 \pm 11,45$ years. The mean systolic and diastolic blood pressure on admission was $206,40 \pm 38,59 \mathrm{mmHg}$ and $116,90 \pm 19,18 \mathrm{mmHg}$. The mean Glasgow coma scale on admission was $6,90 \pm 3,66$. Laboratory findings, which include blood glucose level and white blood cell count was obtained from 10 patients with the mean blood glucose level was $158,70 \pm 39,705$ and the mean white blood cell count was $16630 \pm 6963,72$.

Table 1: The characteristics of brainstem hemorrhage's patients.

\begin{tabular}{ll}
\hline Characteristics & Value \\
Sex, $\mathrm{n}(\%)$ & $6(6)$ \\
Male & $4(4)$ \\
Female & $47,40 \pm 11,45$ \\
Age, years & $206,40 \pm 38,59$ \\
Systolic blood pressure, mmHg & $116,90 \pm 19,18$ \\
Diastolic blood pressure, mmHg & $6,90 \pm 3,66$ \\
Glasgow Coma Scale & $158,70 \pm 39,705$ \\
Blood glucose level, mg/dL & $16630 \pm 6963,72$ \\
White blood cell count, $\mu \mathrm{L}$ & \\
Location, $\mathrm{n}(\%)$ & $3(3)$ \\
Pons & 0 \\
Midbrain & $7(7)$ \\
Pons and midbrain & 0 \\
Pons and medulla oblongata & 0 \\
Pons, midbrain, and medulla & \\
oblongata & \\
Volume, cc & $621,20 \pm 6963,72$ \\
Intraventricular hemorrhage, $\mathrm{n}(\%)$ & \\
(+) & $3(3)$ \\
(-) & $7(7)$ \\
Hydrocephalus, $\mathrm{n}(\%)$ & \\
(+) & $6(6)$ \\
(-) & $4(4)$ \\
Extraventricular drainage, $\mathrm{n}(\%)$ & \\
(+) & $1(1)$ \\
(-) & $9(9)$ \\
Length of stay, days & $2,50 \pm 3,808$ \\
Outcome at discharge, $\mathrm{n}(\%)$ & \\
Good (mRS 0- 3) & \\
Poor (mRS 4-6) & \\
& \\
\hline
\end{tabular}

Hemorrhage occurred in different anatomical locations of the brainstem. $7(7 \%)$ of patients occurred in the pons and midbrain, the remaining 3 (3\%) occurred in the pons. The mean hemorrhage volume was $621,20 \pm 6963,72$. CT finding pointed that intraventricular hemorrhage occurred in $3(3 \%)$ patients and hydrocephalus occurred in $6(6 \%)$ patients. $9(9 \%)$ patients didn't undergo extraventricular drainage.

The mean length of stay was $2,50 \pm 3,808$ days. The outcomes assessed at discharge were good in $2(2 \%)$ patients and poor in $8(8 \%)$ patients.

The correlation between characteristics and the outcomes were shown in table 2. It emphasizes that Glasgow coma scale $(p=0,005)$ with the correlation coefficient 0,807 , location of hemorrhage $(\mathrm{p}=0,016)$ with the correlation coefficient 0,764 , and length of stay $(p=0,035)$ with the correlation coefficient $-0,667$ were correlated with the outcomes.

\section{DISCUSSIONS}

Brainstem hemorrhage is a rare type of stroke hemorrhage. In our cases, among 340 patients with hemorrhagic stroke, the prevalence of brainstem hemorrhage was only $7 \%$. In the previous study, the prevalence of brainstem hemorrhage was $4,6 \% .{ }^{5}$ Other studies that focused on pontine hemorrhage pointed-out that the prevalence was $11,5 \%$ among 881 patients with pontine hemorrhage and $10 \%$ among intracerebral hemorrhage patients. ${ }^{15,16}$

Although rarely encountered, the mortality rate of brainstem hemorrhage was very high. The mortality rate in our study was $60 \%$. This result was in line with other studies that looked at the mortality rate of brainstem hemorrhage and almost have the same results. ${ }^{9,10,11}$ The reason of higher mortality rate of those cases was the damage in the brainstem that depressed consciousness level and, damage the cardiovascular system, as well respiratory system. ${ }^{17,18}$

In our study, most of the patients were male. According to a previous study, the male patient had a higher risk of brainstem hemorrhage. ${ }^{5,9,19}$ Regarding age, this study pointed that the mean age was $47,40 \pm 11,45$. According to Dinsdale, pontine hemorrhage occurred from $40-60$ years old..$^{20}$ Older age was also determined as a risk factor in brainstem hemorrhage and related to poor outcomes.,19

The mean systolic and diastolic blood pressure on admission was $206,40 \pm 38,59$ and $116,90 \pm 19,18$. This result was in accordance to study, by Dziewas et al, that demonstrated that systolic blood pressure $>180 \mathrm{mmHg}$, correlated with poor outcome. ${ }^{21}$ Another study that emphasized pontine hemorrhage also showed that systolic blood pressure $>160 \mathrm{mmHg}$ was significantly related to pontine hemorrhage related-death, whereas diastolic blood pressure $>100 \mathrm{mmHg}$ was marginally related with pontine hemorrhage-related death. ${ }^{10}$ These findings were also consistent with a previous study which explained that hypertension was the risk factor of brainstem hemorrhage. ${ }^{4,6}$

The majority of patients who were admitted to the hospital had GCS $3-8$ and the mean GCS was $6,90 \pm 3,66$. Coma on admission occurred due to rapid destruction of the brainstem, specifically ascending reticular activating system in the upper third of the pontine tegmentum that caused by hemorrhage and the effects of acute hydrocephalus. ${ }^{22}$ Our study found a correlation between low GCS and poor outcomes at discharge. Several authors have reported that lower GCS correlated with poor outcomes. ${ }^{5,9,10,22,23}$

High blood glucose level on admission was found in our study with the mean blood glucose level was $158,70 \pm 39,705$. Hyperglycemia is determined as the risk factor for predicting the functional outcomes in brainstem hemorrhage. Fan et al also reported that increased blood glucose levels related to the poor outcome 90 days after diagnosed with brainstem hemorrhage. ${ }^{14}$ According to an animal study, which conducted by Song et al, intracerebral hemorrhage followed by hyperglycemia can cause brain edema and cell death. ${ }^{24}$ 
Table 2: Correlation of characteristics and the outcome at discharge in patients with brainstem hemorrhage.

\begin{tabular}{|c|c|c|c|c|c|}
\hline \multirow[t]{2}{*}{ Characteristics } & \multirow[t]{2}{*}{ Total $(n=10)$} & \multicolumn{2}{|c|}{ Outcome } & \multirow[t]{2}{*}{$p$-value } & \multirow[t]{2}{*}{ Correlation coefficient ( $r$ ) } \\
\hline & & Good $(n=2)$ & Poor $(n=8)$ & & \\
\hline Sex & & & & 0,356 & 0,327 \\
\hline Male & 6 & 2 & 5 & & \\
\hline Female & 4 & 0 & 3 & & \\
\hline Age, years & $47,40 \pm 11,45$ & & & 0,900 & $-0,046$ \\
\hline$<40$ & 2 & 0 & 2 & & \\
\hline $40-49$ & 3 & 1 & 2 & & \\
\hline $50-59$ & 4 & 1 & 3 & & \\
\hline $60-69$ & 0 & 0 & 0 & & \\
\hline$\geq 70$ & 1 & 0 & 1 & & \\
\hline Systolic blood pressure, $\mathrm{mmHg}$ & $206,40 \pm 38,59$ & & & 0,489 & $-0,248$ \\
\hline$<120$ & 0 & 0 & 0 & & \\
\hline $120-129$ & 1 & 0 & 1 & & \\
\hline $130-139$ & 0 & 0 & 0 & & \\
\hline$\geq 140$ & 1 & 0 & 1 & & \\
\hline$\geq 180$ & 8 & 2 & 6 & & \\
\hline Diastolic blood pressure, $\mathrm{mmHg}$ & $116,90 \pm 19,18$ & & & 0,691 & $-0,144$ \\
\hline$\leq 60$ & 0 & 0 & 0 & & \\
\hline$<80$ & 1 & 0 & 1 & & \\
\hline $80-89$ & 0 & 0 & 0 & & \\
\hline$\geq 90$ & 5 & 1 & 4 & & \\
\hline$\geq 120$ & 4 & 1 & 3 & & \\
\hline Glasgow Coma Scale & $6,90 \pm 3,66$ & & & 0,005 & 0,807 \\
\hline $13-15$ & 1 & 1 & 0 & & \\
\hline $9-12$ & 2 & 1 & 1 & & \\
\hline $3-8$ & 7 & 0 & 7 & & \\
\hline Blood glucose level, mg/dL & $158,70 \pm 39,705$ & & & 0,779 & 0,102 \\
\hline$<150$ & 4 & 1 & 3 & & \\
\hline$\geq 150$ & 6 & 1 & 5 & & \\
\hline White blood cell count & $16630 \pm 6963,72$ & & & 0,645 & $-0,167$ \\
\hline Normal & 1 & 0 & 1 & & \\
\hline Leukocytosis & 9 & 2 & 7 & & \\
\hline Location & & & & 0,010 & 0,764 \\
\hline Pons & 3 & 2 & 1 & & \\
\hline Midbrain & 0 & 0 & 0 & & \\
\hline Pons and midbrain & 7 & 0 & 7 & & \\
\hline Pons and medulla oblongata & 0 & 0 & 0 & & \\
\hline $\begin{array}{l}\text { Pons, midbrain and medulla } \\
\text { oblongata }\end{array}$ & 0 & 0 & 0 & & \\
\hline Volume, cc & $621,20 \pm 6963,72$ & & & 0,221 & 0,425 \\
\hline$<5$ & 2 & 1 & 1 & & \\
\hline $5-10$ & 5 & 1 & 4 & & \\
\hline $10-15$ & 3 & 0 & 3 & & \\
\hline Intraventricular hemorrhage & & & & 0,356 & $-0,327$ \\
\hline$(+)$ & 3 & 0 & 3 & & \\
\hline$(-)$ & 7 & 2 & 5 & & \\
\hline Hydrocephalus & & & & 0,060 & $-0,612$ \\
\hline$(+)$ & 6 & 0 & 6 & & \\
\hline \multirow[t]{2}{*}{ Characteristics } & $\begin{array}{c}\text { Total } \\
(n=10)\end{array}$ & & & $p$-value & $\begin{array}{l}\text { Correlation coefficient } \\
\text { (r) }\end{array}$ \\
\hline & & $\begin{array}{l}\text { Good } \\
(n=2)\end{array}$ & $\begin{array}{l}\text { Poor } \\
(n=8)\end{array}$ & & \\
\hline$(-)$ & 4 & 2 & 2 & & \\
\hline Extraventricular drainage & & & & 0,645 & $-0,167$ \\
\hline$(+)$ & 1 & 0 & 1 & & \\
\hline$(-)$ & 9 & 2 & 7 & & \\
\hline Length of stay, days & $2,50 \pm 3,808$ & & & 0,035 & $-0,667$ \\
\hline$<7$ & 9 & 1 & 8 & & \\
\hline$\geq 7$ & 1 & 1 & 0 & & \\
\hline
\end{tabular}


Our study also found a high white blood cell count on admission. The mean white blood cell count was $16630 \pm 6963,72$. Some authors reported that higher white blood cell count in patients with intracerebral hemorrhage is related to poor outcomes such as a decrease of consciousness, hemorrhage expansion, and intraventricular hemorrhage. ${ }^{25,26}$ However, leukocytosis was not the main factor for predicting the poor outcome in intracerebral hemorrhage patients, other factors were detrimental such as age, initial bleeding volume, and Glasgow coma scale scores on admission. ${ }^{27}$.

Regarding the anatomical location of the brainstem, in this study hemorrhage occurred in the pons and midbrain in the majority of patients. Our study also showed that there was a correlation between hemorrhage that occurred in the pons and the midbrain and the poor outcome. Several authors reported that the expansion of hemorrhage beyond the pons was associated with a poor outcome. ${ }^{10,28}$

The majority of patients studied by Wijdicks and Louis also had a hemorrhage in the pons and midbrain. ${ }^{28}$ Tao et al in their study of factors that influence the functional outcome in pontine hemorrhage patients undergoing surgery, also stated that the expansion to the rostrocaudal especially the midbrain was an independent factor that can predict the functional outcome within 3 months. ${ }^{29}$

Radiological findings such as hemorrhage volume were associated with the poor outcome in the previous study. ${ }^{9,22}$ This study showed no correlation between hemorrhage volume and the outcomes. Extension to the ventricle rarely occurred in our study. Hydrocephalus occurred in most of the patients. Several studies found that acute hydrocephalus was associated with the survival outcome. ${ }^{9,22}$ In the present study, the majority of patients didn't undergo extraventricular drainage even when hydrocephalus occurred in most patients. It happened because most of the patient's family didn't approve.

Length of stay (LOS) is defined as the time that the patient used to receive medical treatment in a hospital. According to Amiman, LOS in hemorrhagic stroke patients is longer than ischemic stroke. ${ }^{30}$ However, in the present study, the mean LOS was 2,50 $\pm 3,808$ days and correlated with the poor outcomes. That was because the majority of patients who came was already in a terminal condition, thus patients died a few hours or 1 day after coming to the hospital.

Characteristics that were not correlated with the outcome of brainstem hemorrhage patients in this study were not fully referenced in clinical practice. The small sample size and the lack of sample variance in each characteristic group cause the possibility of a bias in this study.

\section{ACKNOWLEDGEMENTS}

Authors acknowledged receive no. external fund. Namira Khairunnisa worked on the writing of the paper, Tasya Anggraini Sinaga analysed the data with the SPSS, feda makkiyah corrected the discussion part of the paper.

\section{REFERENCES}

1. Sacco, R.L., Kasner, S.E., Broderick, J.P., Caplan, L.R., Connors, J.J., Culebras, A., Elkind, M.S., George, M.G., Hamdan, A.D., Higashida, R.T. and Hoh, B.L., 2013. An updated definition of stroke for the $21 \mathrm{st}$ century: a statement for healthcare professionals from the American Heart Association/American Stroke Association. Stroke, 44(7), pp.2064-2089.

2. Aguilar, M.I. and Brott, T.G., 2011. Update in intracerebral hemorrhage. The Neurohospitalist, 1(3), pp.148-159.

3. Raison, J.S., Bourbotte, G. and Baum, T.P., 2008. Primary brain stem.

4. Alerhand, S. and Lay, C., 2017. Spontaneous intracerebral hemorrhage. Emergency Medicine Clinics, 35(4), pp.825-845.
5. AlMohammedi, R.M., AlMutairi, H., AlHoussien, R.O., AlOtayan, M.T., AlMutairi, A.K., Bafail, W.O., Khan, A. and Khatri, I.A., 2020. Brainstem hemorrhage is uncommon and is associated with high morbidity, mortality, and prolonged hospitalization. Neurosciences (Riyadh, Saudi Arabia), 25(2), p.91.

6. Ennaqui, K., Makayssi, A., Boufettal, H. and Samouh, N., 2017. Haemorrhagic stroke of the brainstem secondary to postpartum eclampsia: about a case and literature review. The Pan African Medical Journal, 27, pp.266-266.

7. Flaherty, M.L., Woo, D., Haverbusch, M., Sekar, P., Khoury, J., Sauerbeck, L., Moomaw, C.J., Schneider, A., Kissela, B., Kleindorfer, D. and Broderick, J.P., 2005. Racial variations in location and risk of intracerebral hemorrhage. Stroke, 36(5), pp.934-937.

8. Bozinov, O., Hatano, T., Sarnthein, J., Burkhardt, J.K. and Bertalanffy, H., 2010. Current clinical management of brainstem cavernomas. Swiss medical weekly, 140, p.w13120.

9. Takeuchi, S., Suzuki, G., Takasato, Y., Masaoka, H., Hayakawa, T., Otani, N., Yatsushige, H., Shigeta, K., Momose, T., Wada, K. and Nawashiro, H., 2013. Prognostic factors in patients with primary brainstem hemorrhage. Clinical Neurology and Neurosurgery, 115(6), pp.732-735.

10. Matsukawa, H., Shinoda, M., Fujii, M., Takahashi, O. and Murakata, A., 2015. Risk factors for mortality in patients with non-traumatic pontine hemorrhage. Acta Neurologica Scandinavica, 131(4), pp.240-245.

11. Chung, C.S. and Park, C.H., 1992. Primary pontine hemorrhage: a new CT classification. Neurology, 42(4), pp.830-830.

12. Rabinstein, A.A., Tisch, S.H., McClelland, R.L. and Wijdicks, E.F., 2004. Cause is the main predictor of outcome in patients with pontine hemorrhage. Cerebrovascular Diseases, 17(1), pp.66-71.

13. Murata, Y., Yamaguchi, S., Kajikawa, H., Yamamura, K., Sumioka, S. and Nakamura, S., 1999. Relationship between the clinical manifestations, computed tomographic findings and the outcome in 80 patients with primary pontine hemorrhage. Journal of the neurological sciences, 167(2), pp.107-111.

14. Fan, Z., Hao, L., Chuanyuan, T., Jun, Z., Xin, H., Sen, L., Juan, Q., Cao, Y. and Mu, Y., 2018. Neutrophil and platelet to lymphocyte ratios in associating with blood glucose admission predict the functional outcomes of patients with primary brainstem hemorrhage. World neurosurgery, 116, pp.e100-e107.

15. Meguro, T., Kuwahara, K., Tomita, Y., Okuma, Y., Tanabe, T., Muraoka, K., Terada, K., Hirotsune, N. and Nishino, S., 2015. Primary pontine hemorrhage in the acute stage: clinical features and a proposed new simple scoring system. Journal of Stroke and Cerebrovascular Diseases, 24(4), pp.860-865.

16. Wessels, T., Möller-Hartmann, W., Noth, J. and Klötzsch, C., 2004. CT findings and clinical features as markers for patient outcome in primary pontine hemorrhage. American journal of neuroradiology, 25(2), pp.257-260.

17. Annane, D., Trabold, F., Sharshar, T., Jarrin, I., Blanc, A.S., Raphael, J.C. and Gajdos, P., 1999. Inappropriate sympathetic activation at onset of septic shock: a spectral analysis approach. American journal of respiratory and critical care medicine, 160(2), pp.458-465.

18. Sharshar, T., Gray, F., de la Grandmaison, G.L., Hopklnson, N.S., Ross, E., Dorandeu, A., Orlikowski, D., Raphael, J.C., Gajdos, P. and Annane, D., 2003. Apoptosis of neurons in cardiovascular autonomic centres triggered by inducible nitric oxide synthase after death from septic shock. The Lancet, 362(9398), pp.1799-1805.

19. Nishizaki, T., Ikeda, N., Nakano, S., Sakakura, T., Abiko, M. and Okamura, T., 2012. Factors determining the outcome of pontine hemorrhage in the absence of surgical intervention. Open Journal of Modern Neurosurgery, 2(02), pp.17-20.

20. DINSDALE, H.B., 1964. Spontaneous hemorrhage in the posterior fossa: a study of primary cerebellar and pontine hemorrhages with observations on their pathogenesis. Archives of Neurology, 10(2), pp.200-217. 
21. Dziewas, R., Kremer, M., Lüdemann, P., Nabavi, D.G., Dräger, B. and Ringelstein, E.B., 2003. The prognostic impact of clinical and CT parameters in patients with pontine hemorrhage. Cerebrovascular Diseases, 16(3), pp.224-229

22. Jang, J.H., Song, Y.G. and Kim, Y.Z., 2011. Predictors of 30-day mortality and 90-day functional recovery after primary pontine hemorrhage. Journal of Korean Medical Science, 26(1), pp.100-107.

23. Choi, C.H., Park, D.J. and Lee, Y.W., 1997. Clinical Analysis of the Factors Affecting the Prognosis of Spontaneous Pontine Hemorrhage. Journal of Korean Neurosurgical Society, 26(10), pp.1409-1412.

24. Song, E.C., Chu, K., Jeong, S.W., Jung, K.H., Kim, S.H., Kim, M. and Yoon, B.W., 2003. Hyperglycemia exacerbates brain edema and perihematomal cell death after intracerebral hemorrhage. Stroke, 34(9), pp.2215-2220.

25. Behrouz, R., Hafeez, S. and Miller, C.M., 2015. Admission leukocytosis in intracerebral hemorrhage: associated factors and prognostic implications. Neurocritical care, 23(3), pp.370-373.
26. Suzuki, S., Kelley, R.E., Dandapani, B.K., Reyes-Iglesias, Y., Dietrich, W.D. and Duncan, R.C., 1995. Acute leukocyte and temperature response in hypertensive intracerebral hemorrhage. Stroke, 26(6), pp.1020-1023.

27. Di Napoli, M., Godoy, D.A., Campi, V., Del Valle, M., Piñero, G., Mirofsky, M., Popa-Wagner, A., Masotti, L., Papa, F. and Rabinstein, A.A., 2011. C-reactive protein level measurement improves mortality prediction when added to the spontaneous intracerebral hemorrhage score. Stroke, 42(5), pp.1230-1236.

28. Wijdicks, E.F. and Louis, E.S., 1997. Clinical profiles predictive of outcome inpontine hemorrhage. Neurology, 49(5), pp.1342-1346.

29. Tao, C., Li, H., Wang, J. and You, C., 2016. Predictors of surgical results in patients with primary pontine hemorrhage. Turkish neurosurgery, 26(1), pp.77-83.

30. miman, R.C., Tumboimbela, M.J. and Kembuan, M.A., 2016. Gambaran length of stay pada pasien stroke rawat inap di RSUP Prof. Dr. RD Kandou Manado periode Juli 2015-Juni 2016. e-CliniC, 4(2).

\section{GRAPHICAL ABSTRACT}

Primary brainstem hemorrhage is a rare type of hemorrhagic stroke with a very high reported mortality rate in Indonesia.

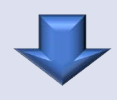

This study aims to demonstrate the mortality rate of cases in a center in Indonesia's rural hospitals. To help reduce the mortality rate, the prognostic factors of several cases were studied.

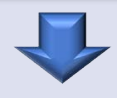

Low prevalence of primary brainstem hemorrhage (7\%). There were correlation between GCS score, brainstem hemorrhage location, and length of stay with the patient's prognosis

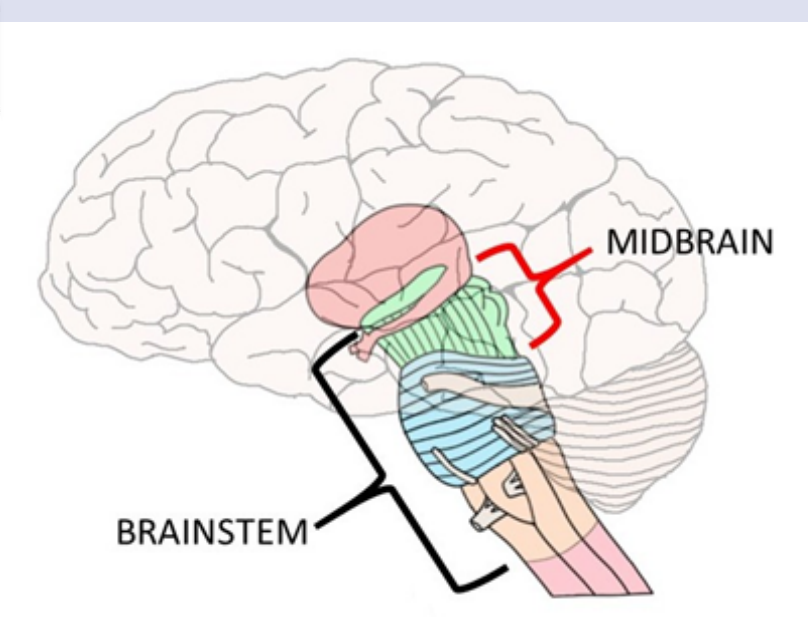

Cite this article: Khairunnisa N, Makkiyah FA, Sinaga TA, Susantingsih T, Nurrizka RH. Prognostic Factors in Predicting Primary Brainstem Hemorrhage Patients: An Experience in Indonesia's Rural Hospital. Pharmacogn J. 2021;13(6): 1445-1449. 